\title{
Perbedaan jumlah mikronukleus mukosa gingiva dan mukosa bukal akibat radiasi radiografi panoramik
}

\author{
Mufida Dzuriyatin Syarifah ${ }^{1 *}$, Rini Widyaningrum ${ }^{2}$, Rurie Ratna Shantiningsih²*
}

\begin{abstract}

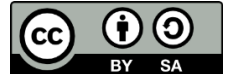

This work is licensed under a Creative Commons Attribution 4.0

Objectives: Panoramic radiography exposure causes DNA damage and micronucleus formation. The gingival mucosa and buccal mucosa were used to identify the number of micronucleus due to radiation exposure because they have a high prevalence of oral cancer in Southeast Asia. This research is aimed to determine the difference between micronucleus formation at the buccal mucosa and the gingival mucosa after exposed by conventional panoramic radiography in the Dentomaxillofacial Radiology Installation of Prof. Soedomo dental hospital, Universitas Gadjah Mada.

Results: Analysis of independent $T$ tests showed that there was a significant difference $(p<0,05)$ in the increasing of micronucleus formation between the buccal mucosa and the gingival mucosa. The average difference in the number of micronucleus were $5,5 / 1000$ cells.

Conclusion: There were differences in the increasing of micronucleus between the buccal mucosa and the gingival mucosa due to exposure of conventional panoramic radiography. The buccal mucosa had higher increase than the gingival mucosa.
\end{abstract}

${ }^{1}$ Program Studi Pendidikan Dokter Gigi, Fakultas Kedokteran Gigi, Universitas Gadjah Mada, Yogyakarta, Indonesia, 55281

${ }^{2}$ Departemen Radiologi Kedokteran Gigi, Fakultas Kedokteran Gigi, Universitas Gadjah Mada, Yogyakarta, Indonesia, 55281

* Correspondence to: Mufida Dzuriyatin 凶mufida_syarifah@yahoo.com

Rurie Ratna Shantiningsih 四rurieratna@ugm.ac.id

Received on: January 2020 Revised on: March 2020 Accepted on: April 2020

Material and Methods: Samples were obtained by rolling the cervical brush against the buccal and gingival mucosa at 10 days after radiation exposure. Samples were stained using the Feulgen-Rossenbeck method and analyzed under binuclear light microscope with a 400x magnification.

Keywords: Micronucleus, radiography, panoramic, mucosa, buccal, gingiva

Cite this article: Syarifah MD, Widyaningrum R, Shantiningsih RR. Perbedaan jumlah mikronukleus mukosa gingiva dan mukosa bukal akibat radiasi radiografi panoramik. Jurnal Radiologi Dentomaksilofasial Indonesia 2020;4(1)11-5. https://doi.org/10.32793/jrdi.v4i1.424

\section{PENDAHULUAN}

Radiografi panoramik atau biasa disebut dengan OPG (Orthopantomograph) adalah salah satu teknik radiografi ekstraoral yang dilakukan dengan menempatkan image receptor di luar tubuh subjek, digunakan dalam pemeriksaan penunjang $d$ kedokteran gigi ${ }^{1}$. Radiografi panoramik digunakan untuk mengidentifikasi kondisi pasien yang tidak terlihat pada saat pemeriksaan klinis, seperti: melihat posisi gigi impaksi, kondisi rongga mulut secara keseluruhan, dan pembengkakan di dalam rongga mulut. Teknik radiografi ini memperlihatkan gambaran tulang kondilus kanan dan kiri, tulang maksila, tulang mandibula, tulang hyoid, sebagian tulang hidung, tulang belakang, gigi geligi beserta lengkung gigi. ${ }^{1-3}$ Berdasarkan cara processing, teknik radiografi panoramik dibedakan menjadi panoramik konvensional dan panoramik digital. Teknik radiografi panoramik konvensional masih banyak digunakan sampai saat ini, karena teknik ini memiliki harga yang lebih terjangkau dibandingkan dengan teknik radiografi panoramik digital. Teknik radiografi panoramik digital juga memerlukan tenaga ahli yang dapat mengoperasikan komputer. ${ }^{4}$
Dosis efektif yang digunakan pada teknik radiografi panoramik konvensional sebesar 16-21 $\mu \mathrm{Sv}$. Batas paparan radiografi panoramik yang sering digunakan berkisar 60-90 kV dengan arus sebesar 5$10 \mathrm{~mA}$, sedangkan waktu yang digunakan untuk paparan 5-20 detik. ${ }^{2,5}$

Radiografi panoramik konvensional memiliki efek terhadap tubuh pada tingkat molekul, genom, dan sel. Efek tersebut muncul karena reaksi ionisasi yang terjadi di dalam sel. Reaksi ionisasi akan memicu terbentuknya radikal bebas dan memicu terjadinya reaksi oksidasi pada molekul disekitarnya. Kedua reaksi ini apabila mengenai kromosom sel dapat menyebabkan pemutusan ikatan basa nukleotida yang menimbulkan terjadinya kerusakan sel serta kegagalan dalam proses pembelahan sel. ${ }^{3,6}$ Kerusakan ini ditandai dengan terbentuknya mikronukleus. Mikronukleus merupakan nukleus kecil yang terbentuk dari fragmen kromosom yang gagal bergabung dalam nukleus utama. Kromosom yang gagal bergabung juga mengalami dekondensasi dan membentuk nukleus bulat kecil yang tertutup oleh membrannya 
sendiri di sitoplasma. Mikronukleus dapat dilihat sebagai sisa dari kromosom yang gagal terbentuk setelah mitosis pada fase interfase sel. ${ }^{7}$ Mikronukleus tampak seperti inti sel utama dengan warna yang sama dan berada dalam sitoplasma yang sama, tetapi memiliki ukuran yang lebih kecil dari inti sel utama.,

Mikronukleus memiliki diameter sekitar $1 / 5$ sampai $1 / 3$ dari diameter inti sel utama $( \pm 6 \mu \mathrm{m})$ Mikronukleus erat kaitannya dengan proses repair serta waktu turnover yang dimiliki oleh tiap sel. Tubuh akan sesegera mungkin melakukan sistem pemulihan apabila terdapat mikronukleus di dalam sel tubuh dengan tujuan untuk menghilangkan dan menghentikan proses pembelahan sel yang dapat menghasilkan mikronukleus. Sel yang memilik mikronukleus akan terkelupas pada saat turnover sel, sehingga tidak ada lagi sel yang mengandung mikronukleus dalam jaringan. ${ }^{9,10}$

Pembentukan mikronukleus selain diakibatkan oleh efek paparan radiasi, dapat disebabkan juga oleh penyakit sistemik diantara lain diabetes melitus (DM), penyakit benchet, vitiligo, dan lainlain. Pembentukan mikronukleus pada penyakit diabetes melitus disebabkan oleh peningkatan glukosa darah yang berefek pada terjadinya kerusakan oksidatif terhadap berbagai biomoleku yang menyebabkan kerusakan DNA. ${ }^{11}$ Pembentukan mikronukleus pada penyakit benchet disebabkan karena adanya peningkatan kerusakan oksidatif yang berkaitan dengan kerusakan DNA ${ }^{11}$ Pembentukan mikronukleus pada penyakit vitiligo disebabkan proses patogenesis dari penyakit tersebut. Proses patogenesis vitiligo menimbulkan kerusakan sel, kerusakan genetik dan peningkatan kerusakan oksidatif ${ }^{11}$. Pembentukan mikronukleus juga dapat dipengaruhi oleh jenis kelamin dan usia. Pembentukan mikronukleus terjadi lebih tingg pada perempuan dibandingkan dengan laki-laki. Begitu pula dengan usia, pada usia lebih dari 50 tahun menunjukkan terjadinya pembentukan mikronukleus lebih tinggi dibandingkan dengan usia muda. ${ }^{12}$

Mukosa gingiva dan mukosa bukal merupakan area anatomi yang digunakan untuk mengidentifikasi jumlah mikronukleus akibat paparan radiasi. Kedua area anatomi tersebut memiliki struktur epitel yang berbeda. Mukosa gingiva memiliki struktur lapisan epitel skuamosa stratifikasi keratinisasi dengan ketebalan sekitar 100-200 $\mu \mathrm{m}$ dan waktu turn over selama 10 hari, sedangkan mukosa bukal memiliki lapisan epitel setebal $500-800 \mu \mathrm{m}$ dengan struktur epitel skuamosa stratifikasi non keratinisasi dan waktu turn over selama 14 hari. $^{13-16}$ Mukosa gingiva dengan struktur epitel keratinisasi memiliki sifat yang tahan terhadap trauma fisik maupun kimia dibandingkan mukosa bukal dengan epitel keratinisasi. Trauma fisik dan kimia tersebut dapat menimbulkan terjadinya kerusakan DNA dan se akibat paparan radiasi. ${ }^{17}$ Pengambilan sampel mikronukleus dilakukan pada hari ke-10 setelah paparan radiografi panormaik konvensional, dikarenakan pada hari ke-10 merupakan fast turn over sel sehingga diharapkan terjadi pembentukan mikronukleus yang maksimal. ${ }^{18,19}$ Berdasarkan teori tersebut dapat dirumuskan suatu permasalahan apakah terdapat perbedaan jumlah mikronukleus antara mukosa gingiva dan mukosa bukal akibat paparan radiografi panoramik konvensional. Penelitian ini dilakukan untuk memberikan sumbangsih pengetahuan terkait efek radiografi panoramik konvensional terhadap kedua mukosa tersebut dan memberikan informasi pentingnya proteksi terhadap paparan radiasi sinar-X.

\section{BAHAN DAN METODE}

Penelitian ini telah disetuji Komite Etik Penelitian FKG UGM No.001645/KKEP/FKG-UGM/ $E C / 2018$ dan merupakan penelitian observasional analitik dengan rancangan penelitian cross sectional. Subjek yang digunakan dalam penelitian ini berjumlah 10 orang, jumlah tersebut disesuaikan dengan penelitian mikronukleus sebelumnya yang menggunakan jumlah sampel sebanyak 10 orang. Subjek memiliki indikasi dilakukan pemeriksaan radiografi panoramik konvensional di Instalasi Radiologi RSGM UGM (Rumah Sakit Gigi dan Mulut Universitas Gadjah Mada) Prof Soedomo dan memenuhi kriteri inklusi. Kriteria inklusi dalam penelitian ini sebagai berikut: pasien berusia 18-25 tahun, pasien bersedia mengisi informed consent dan bersedia kembali lagi pada hari ke-10 setelah paparan radiasi, pasien tidak menderita penyakit periodontal, tidak memiliki kelainan di rongga mulut, tidak memiliki riwayat penyakit sistemik, tidak merokok, tidak mengkonsumsi alkohol, tidak menerima paparan radiasi selama 2 minggu terakhir dan tidak menggunakan obat kumur minimal 3 minggu sebelumnya.

Seluruh subjek mendapatkan paparan radiografi panoramik konvensional dengan mesin bermerek Yoshida Panoura ${ }^{\circledR}$ dengan spesifikasi tegangan sebesar 70-90 kVp, arus $10 \mathrm{~mA}$, dan lama paparan selama 12 detik. Jarak penyinaran yang digunakan $37,6 \mathrm{~cm}$ dengan dosis laju sebesar $47 \mu \mathrm{Sv}$ dalam sekali paparan. ${ }^{20}$ Pengambilan sampel dilakukan 10 hari setelah dilakukan paparan radiografi panoramik konvensional pada mukosa bukal dan mukosa gingiva. Pengambilan sampel dilakukan dengan cara swab menggunakan cervical brush pada mukosa bukal dan untuk mukosa gingiva diambil pada gingiva di atas gigi insisivus rahang atas kanan. Hasil swab diapus pada slide yang sebelumnya telah ditetesi dengan larutan $\mathrm{NaCl}$ $0,09 \%$ sebanyak 2 tetes. Slide selanjutnya dilakukan pewarnaan menggunakan metode FeulgenRossenbeck. Preparat yang telah diwarnai dilakukan proses dehidrasi dan mounting.

Preparat tersebut selanjutnya dilakukan pengamatan menggunakan mikroskop cahaya binuklear dengan perbesaran 400 kali. Pengamatan mikronukleus menggunakan bantuan aplikasi Optilab Viewer ${ }^{\circledR}$ dilakukan pada tiap 1000 sel dalam setiap 1 preparat. Mikronukleus yang dihitung dalam penelitian ini yang sesuai dengan karakteristik berikut: ${ }^{21}$ (a) berbentuk bulat, (b) berada di sekitar inti sel utama dan pada sitoplasma 

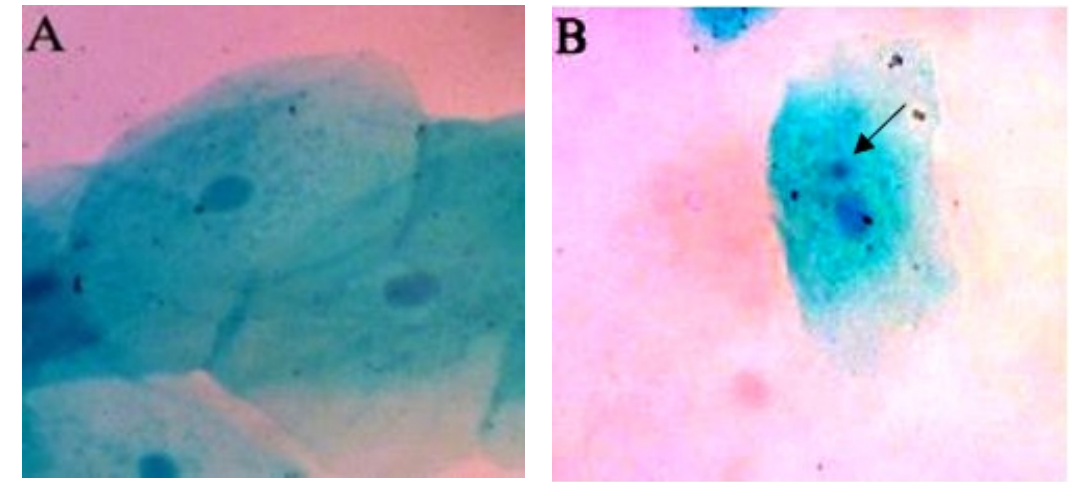

Gambar 1. Hasil pengamatan kondisi inti sel yang ditunjuk dengan anak panah (A) inti sel normal, (B) mikronukleus

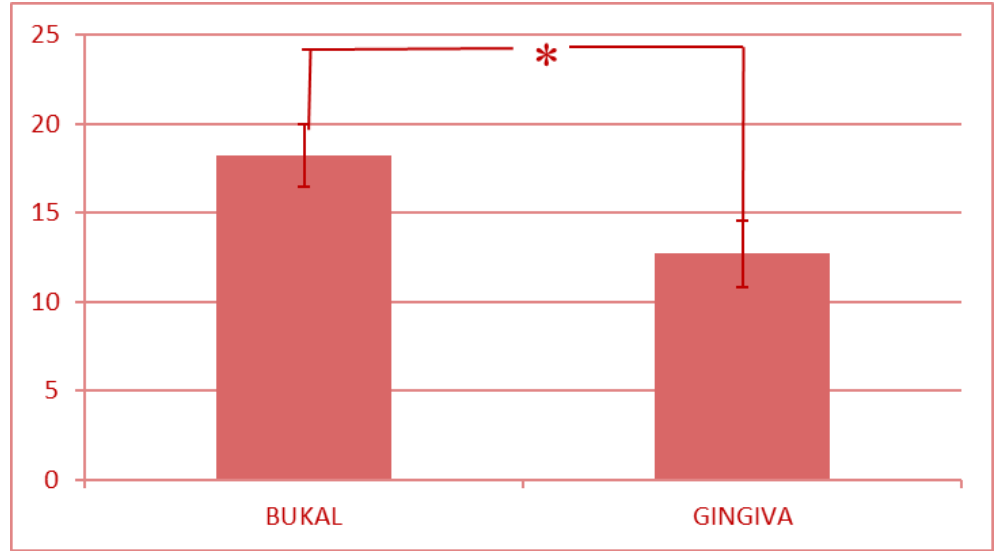

Gambar 2. Histogram rerata dan simpangan baku jumlah mikronukleus 10 hari setelah paparan pada mukosa bukal dan mukosa gingiva

yang sama, (c) memiliki warna yang sama dengan inti sel utama, (d) diameter kurang dari $1 / 3$ dari inti sel utama, (e) tekstur yang dimiliki sama dengan inti sel utama, dan (f) tidak mengalami tumpang tindih dengan inti sel utama.

Data yang telah terkumpul selanjutnya dianalisis secara statistik menggunakan uji $\mathrm{T}$ tidak 2 . berpasangan yang sebelumnya telah dilakukan uji normalitas dan uji homogenitas.

\section{HASIL}

Penelitian ini dilakukan di Instalasi Radiolog Dentomaksilofasial RSGM UGM Prof Soedomo dan hasilnya diamati di Laboratorium Histologi UGM selama kurang lebih 2 bulan. Penelitian ini menghitung dan mengamati jumlah mikronukleus pada mukosa gingiva dan mukosa bukal 10 hari setelah dilakukan paparan radiografi panoramik konvensional. Mikronukleus memiliki ciri-ciri yang spesifik sehingga mudah dibedakan dengan kondisi inti sel yang lain. Kondisi kelainan inti sel lain akibat paparan radiasi tidak dilakukan pengamatan dan penghitungan dalam penelitian ini. Penelitian ini berfokus untuk membandingkan peningkatan mikronukleus pada mukosa bukal dan mukosa gingiva akibat paparan radiografi panoramik konvensional. Gambar kelainan kondisi inti sel lain yang disajikan pada penelitian ini hanya sebagai pembanding terhadap struktur mikronukleus yang benar. Contoh gambar mikronukleus pada penelitian ini disajikan pada Gambar 1.
Gambar 1 menunjukkan gambaran antara inti sel normal, mikronukleus, dan kondisi inti sel yang lain. Data jumlah mikronukleus yang telah didapatkan berupa rerata dan simpangan baku pada mukosa gingiva dan mukosa bukal. Data tersebut telah ditunjukkan pada histogram Gambar 2.

Gambar 2 menunjukkan hasil rerata dan simpangan baku jumlah mikronukleus pada mukosa bukal dan mukosa gingiva 10 hari setelah paparan radiasi. Hasil rerata dan simpang baku pada mukosa bukal didapatkan sebesar 18,2 $\pm 1,751 / 1000$ sel dan pada mukosa gingiva didapatkan hasil sebesar $12,7 \pm 1,889$ / 1000 sel. Hal ini menunjukkan adanya rerata perbedaan peningkatan jumlah mikronukleus antara mukosa bukal dengan mukosa gingiva sebesar 5,5 / 1000 sel. Hasil tersebut kemudian dianalisis menggunakan uji T tidak berpasangan, sebelumnya dilakukan uji normalitas dan uji homogenitas terlebih dahulu sebagai prasyarat dilakukan uji $\mathrm{T}$ tidak berpasangan. Hasil dari uji normalitas dan uji homogenitas telah disajikan pada Tabel 1.

Hasil uji normalitas menggunakan Shapiro-Wilk didapatkan bahwa data terdistribusi normal karena hasil yang didapatkan lebih dari 0,05. Uji homogenitas yang dilakukan dengan uji Levene juga mendapatkan hasil yang serupa yaitu data bervariasi homogen, karena signifikansi yang didapat lebih dari 0,05. Hasil uji $T$ tidak berpasangan disajikan pada Tabel 2 .

Tabel 2 menyajikan hasil uji T tidak berpasangan yang menunjukkan adanya perbedaan yang 
Tabel 1. Uji normalitas (Shapiro-Wilk) dan uji homogenitas (Levene test)

\begin{tabular}{|c|c|c|c|c|}
\hline \multirow{2}{*}{ Lokasi } & \multicolumn{3}{|c|}{ Shapiro-Wilk } & \multirow{2}{*}{$\begin{array}{l}\text { Levene test } \\
\text { Signifikansi }\end{array}$} \\
\hline & Jumlah Data & Statistik & Signifikansi & \\
\hline Bukal & 10 & 0,932 & 0,473 & \multirow{2}{*}{0,769} \\
\hline Gingiva & 10 & 0,909 & 0,275 & \\
\hline
\end{tabular}

Tabel 2. Hasil uji T tidak berpasangan dengan signifikansi (*) $p<0,05$

\begin{tabular}{ccc}
\hline & Sampel & Uji T tidak berpasangan \\
\cline { 3 - 3 } Mikronukleus & Equal varinces assumed & Signifikansi (2-tailed) \\
\cline { 2 - 3 } & Equal variances not assumed & $0,000^{*}$ \\
\hline
\end{tabular}

signifikan $(p<0,05)$ antara peningkatan jumlah mikronukleus di mukosa bukal dengan mukosa gingiva 10 hari setelah dilakukan paparan radiografi panoramik konvensional.

\section{DISKUSI}

Reaksi ionisasi yang terjadi karena paparan sinar-X dapat menimbulkan terbentuknya radikal bebas. Radikal bebas yang terbentuk dapat mengakibatkan terjadinya reaksi oksidasi bagi molekul di sekitarnya. Kedua reaksi ini apabila mengenai kromosom dapat menimbulkan pemutusan ikatan basa nukleotida dan menyebabkan DSB (Double Strand Breakage) pada sel. Hal ini menyebabkan terjadinya kerusakan sel dan kegagalan dalam proses pembelahan sel yang ditandai dengan terbentuknya mikronukleus. ${ }^{2,3,9}$ Mikronukleus terbentuk karena adanya kegagalan dalam proses pembelahan sel, terdapat fragmenfragmen kromosom yang gagal bergabung dengan inti sel utama sehingga membentuk struktur tersendiri yang terpisah dari inti sel utama. ${ }^{7-9,21}$

Histogram pada Gambar 2 menunjukkan bahwa terdapat rerata perbedaan peningkatan jumlah mikronukleus antara mukosa bukal dengan mukosa gingiva sebesar 5,5 / 1000 sel. Hal ini dibuktikan dengan dilakukannya uji $T$ tidak berpasangan dan didapatkan hasil sebesar 0,000 $(p<0,05)$ yang menunjukkan bahwa terdapat perbedaan jumlah mikronukleus yang signifikan antara mukosa bukal dengan mukosa gingiva pada 10 hari setelah paparan radiografi panoramik konvensional. Perbedaan jumlah mikronukleus ini didasari oleh karakteristik dari kedua mukosa yang berbeda. Mukosa bukal merupakan lining mukosa dan memiliki struktur epitel skuamosa stratifikasi non keratinisasi serta waktu turn over selama 14 hari. Mukosa gingiva merupakan masticatory mukosa dengan struktur epitel skuamosa stratifikas keratinisasi dan waktu turn over selama 10 hari. ${ }^{13-15}$ Menurut Kesidi et al. (2017) perbedaan karakteristik ini dapat berpengaruh terhadap efek paparan radiasi yang terjadi pada tubuh. Mukosa bukal dengan epitel non keratinisasi memiliki sifat yang tidak tahan terhadap trauma fisik maupun kimia, sehingga rentan terhadap kerusakan sel maupun kerusakan DNA setelah dilakukan paparan radiasi. Mukosa gingiva dengan epitel keratinisasi memiliki sifat yang lebih tahan terhadap trauma fisik maupun kimia, sehingga efek yang ditimbulkan setelah paparan radiasi lebih minimal dibandingkan mukosa bukal. Hal ini sesuai dengan hasil penelitian yang menunjukkan bahwa mukosa bukal memiliki hasil rerata dan simpangan baku yang lebih tinggi daripada mukosa gingiva (Gambar 2).

Hasil penelitian ini sejalan dengan Sandhu et al. (2015) yang menunjukkan bahwa terdapat peningkatan jumlah mikronukleus yang signifikan pada mukosa bukal setelah dilakukan paparan radiografi panoramik konvensional. Penelitian yang dilakukan Sandhu et al. (2015) diperoleh hasil rerata \pm simpangan baku pada mukosa bukal sebesar 6,4 $\pm 2 / 1000$ sel. $^{22}$ Penelitian Cerqueira et al. (2008) menunjukkan pula adanya peningkatan jumlah mikronukleus yang signifikan pada mukosa gingiva setelah dilakukan paparan radiasi. Hasil rerata yang diperoleh 1,55 / 1000 sel pada hari ke 10 setelah dilakukan paparan radiasi ${ }^{18}$. Hasil penelitian ini juga sejalan dengan hasil penelitian sebelumnya yang dilakukan di Instalasi Radiologi Dentomaksilofasial RSGM UGM Prof. Soedomo yaitu penelitian Shantiningsih dan Diba (2018) yang menyatakan terdapat peningkatan jumlah mikronukleus secara signifikan pada mukosa gingiva setelah dipapar radiasi sinar-X. Hasil rerata jumlah mikronukleus pada mukosa gingiva di penelitian yang dilakukan Shantiningsih dan Diba (2018) adalah 12,4 $\pm 3,08$ / 1000 sel hampir sama dengan hasil penelitian ini sebesar $12,7 \pm 1,889 / 1000$ sel. $^{23}$ Penelitian Shantiningsih dan Diba (2018) meneliti tentang peningkatan jumlah mikronukleus pada mukosa gingiva 10 hari setelah dipapar radiasi sinar $-X$. Berbeda dengan penelitian ini, pengamatan dilakukan pada mukosa bukal dan mukosa gingiva untuk membandingkan perbedaan peningkatan jumlah mikronukleus antara kedua mukosa tersebut pada 10 hari setelah dilakukan paparan radiasi sinar $-X$.

Mikronukleus erat kaitannya dengan proses perbaikan tubuh, apabila terdapat mikronukleus maka tubuh sesegera mungkin untuk melakukan proses repair. Peningkatan mikronukleus pada penelitian ini diharapkan akan hilang bersamaan dengan proses turn over sel epitel. ${ }^{10}$ Kemunculan mikronukleus bersifat reversibel, hal ini didukung oleh hasil penelitian sebelumnya ${ }^{10}$ bahwa terjadi penurunan secara kuantitatif jumlah mikronukleus pada hari ke-14 setelah paparan radiografi 
panoramik. Dengan demikian, pasien tidak perlu takut untuk melakukan pemeriksaan radiologi dikarenakan efek yang ditimbulkan berupa terbentuknya mikronukleus bersifat reversibel.

Walaupun efek yang timbul bersifat reversibel, tetap diperlukan kehati-hatian dalam menggunakan teknik radiografi panoramik konvensional karena dosis yang digunakan relatif besar dibandingkan dengan radiografi panoramik digital. Radiografi panoramik digital memiliki dosis efektif sebesar 5 $14 \mu \mathrm{Sv}$, memiliki range yang lebih keci dibandingkan radiografi panoramik konvensional dengan rentang dosis 16-21 $\mu \mathrm{Sv}^{5}{ }^{5}$ Dokter gigi harus menerapkan prinsip ALARA dalam menangani pasien yang membutuhkan pemeriksaan penunjang radiologi. Nilai batas dosis radiasi yang telah ditetapkan oleh BAPETEN untuk mengurangi efek radiasi pada individu sebesar $1 \mathrm{mSv}$ per tahun untuk masyarakat umum dan $20 \mathrm{mSv}$ per tahun untuk pekerja (radiografer). Penelitian in menggunakan mesin radiografi panoramik Yoshida Panoura dengan laju dosis sebesar $47 \mu \mathrm{Sv}^{3,20,24}$

\section{SIMPULAN}

Peningkatan jumlah mikronukleus pada mukosa bukal lebih tinggi dibandingkan dengan mukosa gingiva 10 hari setelah dipapar radiografi panoramik konvensional.

\section{DAFTAR PUSTAKA}

1. Iannucci MJ, Howerton L. Dental Radiography Principles and Techniques. 5th ed. St. Louis Missouri: Elsevier; 2017. 5 p.

2. Russo P. Handbook of X-ray Imaging Physics and Technology. Boca Raton: CRC Press; 2018. 425-431, $450 \mathrm{p}$

3. White SC, Pharoah MJ. Oral Radiology Principles And Interpretation. 7th ed. St. Louis Missouri: Elseveier Mosby; 2014. 1,17,32,166.

4. Farman AG. Panoramic Radiology Seminars on Maxillofacia Imaging and Interpretation. Berlin: Springer; 2007. 29 .

5. Visser, H., Hermann, K.P., Bredemeier, S., Kohler B. Comparison of Dosimetry in Conventional and Digital Panoramic Radiography. Mund Kiefer GesichtsChir. 2000;2000 (4):213-6.

6. Shantiningsih RR, Suwaldi, Astuti I, Mudjosemedi M. Korelasi antara jumlah mikronukleus dan ekspresi 8-oxo-dG akibat paparan radiografi panoramic (The correlation of micronucleus formation and 8-oxo-dG expression due to the panoramic radiography exposure). Dent J. 2013;46(3):119-23.

7. McIntosh JR. Mechanism of Mitosis Chromosom Segregation. Basel: MDPI; 2017. 306-307 p.

8. Goncharuk VV. Drinking Water Physics, Chemistry and Biology. Switzerland: Springer; 2014. 364-365 p.

9. Shantiningsih RR. The Number of Micronucleus Between Single and Repeated X-rays Exposure of Panoramic Radiography Patients. 2nd Int Jt Symp Oral Dent Sci. 2012;15.

10. Shantiningsih, R.R., Diba, S.F., Awinda, A. \& Rozaq Al. Increasing The Number of Micronucleus from Dental Radiation Effect Until 14th Day After Exposure. Int Symp Oral Dent Sci. 2013;1-9.

11. Torres-bugarín $\mathrm{O}$, Romero NM, Luisa M, Ibarra R, Flores-garcía A, Aburto PV, et al. Genotoxic Effect in Autoimmune Diseases Evaluated by the Micronucleus Test Assay: Our Experience and Literature Review. J Biomed Biotechnol. 2015;2015(4):111.

12. Astbury C. Clinical Cytogenetics Clinics in Laboratory Medicine. Philadelphia: Saunders; 2011. $499 p$.

13. Bergmeier LA. Oral Mucosa in Health and Disease: A Concise Handbook. London: Springer; 2018. 6-7 p.

14. Berkovitz, B.K.B., Holand, G.R., \& Moxha BJ. Oral Anatomy, Histology and Embriology. 5th editio. China: Elsevier; 2018. 273-275 p.

15. Fehrenbach MJ, Popowics T. Ilustrated Dental Embryology, Histology, and Anatomy. 4th ed. Missouri: Elsevier; 2016. 120 $p$.

16. Singh, M. \& Salnikova M. Novel Approaches and Strategies for Biologics, Vaccine and Cancer Therapies. waltham: Elsevier 2015. 95 p.

17. Kesidi S, Maloth KN, Vinay K, Reddy K, Geetha P. Genotoxic and cytotoxic biomonitoring in patients exposed to full mouth radiographs - A radiological and cytological study. J Oral Maxillofac Radiol. 2017;5(1):1-6.

18. Cerqueira EM., Meireles JR., V.C. Junqueira, Gomes-Filho IS, Trindade S, Machado-Santelli GM. Genotoxic Effects of X-rays on Keratinized Mucosa Cells During Panoramic Dental Radiography. Dentomaxillofacial Radiol. 2008;37(7):398-403.

19. Waingade $M$, Medikeri RS. Analysis of micronuclei in buccal epithelial cells in patients subjected to panoramic radiography. Indian J Dent Res. 2012;23(5):574-8.

20. Kurniawati L. Kalibrasi Spasial Citra Radiografi dan Kalibrasi Dosis Mesin Sinar-X Panoramik Gigi. UGM; 2013.

21. Arora P, Devi P, Wazir SS. Evaluation of Genotoxicity in Patients Subjected to Panoramic Radiography by Micronucleus Assay on Epithelial Cells of the Oral Mucosa. J Dent Tehran Univ Med Sci. 2014;11(1):1-9.

22. Sandhu M, Mohan V, Kumar JS. Evaluation of genotoxic effect of X-rays on oral mucosa during panoramic radiography. J Indian Acad Oral Med Radiol. 2015;27(1):25-8.

23. Shantiningsih RR, Diba SF. Biological changes after dental panoramic exposure: conventional versus digital. Dent J. 2018;51(1):25-8.

24. Hiswara E. Buku Pintar Proteksi dan Keselamatan Radiasi di Rumah Sakit. Jakarta: Batan Press; 2015. 26-28 p. 